\title{
A Repurposed Chemotherapy Drug as C1 Synthon
}

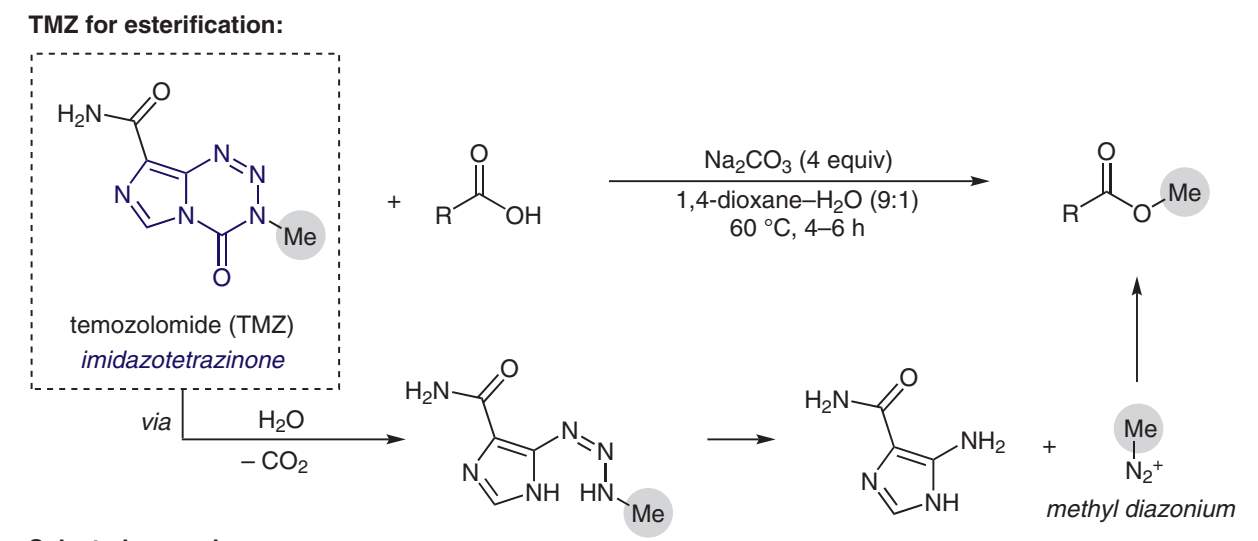

Selected examples:<smiles>[X]c1ccc(C(=O)OC)cc1</smiles>

$70 \%$ yield $(X=H)$ $88 \%$ yield $\left(X=\mathrm{NMe}_{2}\right)$ $83 \%$ yield $(X=\mathrm{OMe})$ $83 \%$ yield $\left(\mathrm{X}=\mathrm{CH}_{2} \mathrm{OTHP}\right)$ $79 \%$ yield $\left(\mathrm{X}=\mathrm{CH}_{2} \mathrm{OMOM}\right)$

TMZ for cyclopropanation:<smiles>COC(=O)C1CN(C(=O)OC(C)(C)C)CCN1C(=O)OCc1ccccc1</smiles><smiles>COC(=O)C(C)c1ccc2c(c1)[nH]c1ccc(Cl)cc12</smiles>
$\mathrm{HO}$ $88 \%$ yield

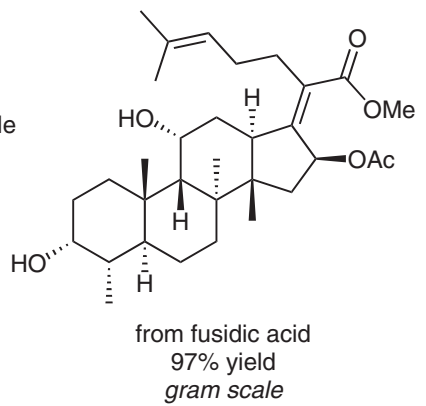

$$
\curvearrowright \frac{\begin{array}{c}
\mathrm{TMZ}(3 \text { equiv) } \\
\mathrm{Fe}(\mathrm{TPP}) \mathrm{Cl}(5 \mathrm{~mol} \%)
\end{array}}{6 \mathrm{M} \mathrm{KOH}}
$$

Selected examples:<smiles>COc1ccc(C2CC2)cc1</smiles>

$91 \%$ yield<smiles>COc1cccc(C2CC2)c1</smiles>

$87 \%$ yield

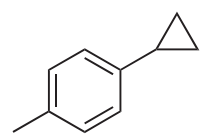

$55 \%$ yield

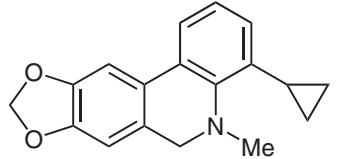

$40 \%$ yield
Chemistry in

Medicine and

Biology

Key words

methylation

temozolomide

diazomethane surrogates
Significance: The reagent diazomethane is employed in the formation of methyl esters, as well as for cyclopropanation reactions; however, it poses a severe risk of explosion and inhalation toxicity. In the search for alternative reagents, the authors identify the cancer chemotherapy drug temozolomide (TMZ), which is designed to methylate DNA in cancer cells.
Comment: TMZ is a weighable solid, non-explosive and not acutely toxic. Upon hydrolysis and release of methyl diazonium, TMZ methylates a broad range of carboxylic acids. Notably, the protecting groups THP and MOM are stable to the reaction conditions. Furthermore, catalysis with $\mathrm{Fe}(\mathrm{TPP}) \mathrm{Cl}$ enables the cyclopropanation of several styrenes. 